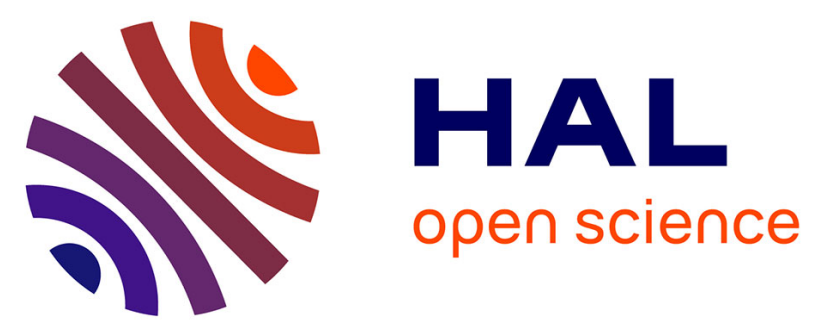

\title{
The divine Plato among Greeks and Romans: Banquet literature and the making of cultural memory in the Graeco-Roman Empire
}

Anthony Andurand, Corinne Bonnet

\section{- To cite this version:}

Anthony Andurand, Corinne Bonnet. The divine Plato among Greeks and Romans: Banquet literature and the making of cultural memory in the Graeco-Roman Empire. Archimède: archéologie et histoire ancienne, 2019, La République "gréco-romaine" des lettres: construction des réseaux savants et circulation des savoirs dans l’Empire romain, HS Nº1, pp.42-53. halshs-02091579

\section{HAL Id: halshs-02091579 \\ https://shs.hal.science/halshs-02091579}

Submitted on 5 Apr 2019

HAL is a multi-disciplinary open access archive for the deposit and dissemination of scientific research documents, whether they are published or not. The documents may come from teaching and research institutions in France or abroad, or from public or private research centers.
L'archive ouverte pluridisciplinaire HAL, est destinée au dépôt et à la diffusion de documents scientifiques de niveau recherche, publiés ou non, émanant des établissements d'enseignement et de recherche français ou étrangers, des laboratoires publics ou privés. 


\title{
THE DIVINE PLATO AMONG GREEKS AND ROMANS: BANQUET LITERATURE AND THE MAKING OF CULTURAL MEMORY IN THE GRAECO-ROMAN EMPIRE [1]
}

\author{
Anthony ANDURAND \\ Docteur en Sciences de l'Antiquité \\ Université Toulouse - Jean Jaurès \\ EA 4601 PLH-ERASME \\ anthonyandurand@yahoo.fr
}

\author{
Corinne BONNET \\ Professeur d'Histoire grecque \\ Université Toulouse - Jean Jaurès \\ EA 4601 PLH-ERASME \\ cbonnet@univ-tlse2.fr
}

RÉSUMÉ

Paradigmatic figures and memorable episodes from the Greek and Roman past are one of the key materials which underlie the discussions performed in Plutarch's Quaestiones convivales. In this learned polyphony, largely based on the conversation with ancient authors (hoi palaioi), the "divine Plato" (Per., $8,2)$, celebrated as "a philosopher pre-eminent in reputation and in influence" $(Q C, 700 \mathrm{~B})$, assumes the role of a "patron saint" of a new Mediterraneanwide Greek culture. In the opening prologues as in the narrative sequences and the intellectual and ritual practices outlined in this work, Plato emerges as one of the main references of Plutarch's sympotic community. Through the analysis of this tutelary figure and its cultural significance in the Quaestiones convivales, this paper aims at emphasising the dynamics KEYWORDS and strategies which support Plutarch,

Plato,

Greek culture,

Roman Empire, symposium. the making of a shared cultural memory within the Graeco-Roman "Republic of Letters".
Les grandes figures exemplaires et les épisodes mémorables du passé de la Grèce et de Rome constituent un des matériaux à partir desquels s'élaborent, au présent, les discussions mises en scène dans les Propos de table. Dans cette polyphonie savante, largement fondée sur le dialogue avec les Anciens (hoi palaioi), la figure du « divin » Platon (Per., 8.2), « le premier des philosophes par la réputation et par l'autorité » $(Q C$, 700B), occupe une place de premier plan, celle d'une sorte de « saint patron » d'un hellénisme dilaté à l'échelle de l'Empire. Dans les prologues placés au seuil de chaque livre comme dans la succession des séquences narratives et les pratiques savantes et rituelles qu'elles décrivent, le philosophe s'affirme en effet comme l'une des références privilégiées de la société plutarquéenne des banquets savants. À travers l'analyse de cette figure tutélaire et de la signification dont elle est investie dans les Propos de table, cette contribution se propose de mettre en lumière les opérations et les stratégies que mobilise, dans I'espace d'une République «gréco-romaine » des lettres, la fabrique d'une mémoire savante partagée, ancrée dans des figures « mythiques ».
Mots-CLÉs
Plutarque,
Platon,
hellénisme,
Empire romain,
symposium.

Article accepté après évaluation par deux experts selon le principe du double anonymat 
Sympotic literature offers excellent material for outlining the development and consolidation of a "Graeco-Roman Empire" - defined as a "fait de culture grecque et de pouvoir romain" [2] - with special emphasis on intellectual circles and communities. From Plutarch to Athenaeus, the symposium is conceived of as a strategic and performative space for sharing and mediation, as a "city of scholars" that delineates the main features of an all-embracing cultural memory, nurtured by knowledge and connivance. In terms of communities, cultural traditions and practices, the sympotic microcosm provides a rich observatory for exploring the codes and ramifications of a GraecoRoman "Republic of letters", shaped by the cultural model of Greece and the dynamics of Roman power. On this basis, this paper investigates the treatment of exemplary figures in Plutarch's Quaestiones convivales, by focusing on the specific and paradigmatic

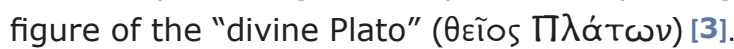

Composed in the early second century CE, the Quaestiones Convivales [4] are presented as a collection of memories written down at the request of Plutarch's Roman friend, Sosius Senecio (to whom the text is also dedicated). According to the programme outlined in the first prologue, this work aims

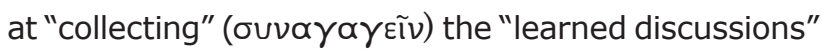
( friends and acquaintances during banquets which took place "both at Rome in your company and among

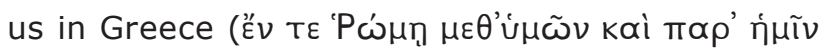

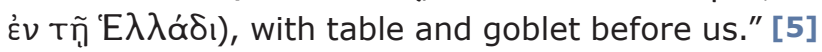
Deeply imbued with the cultural practices and the literary traditions of the world of the symposium, the Quaestiones convivales draw their inspiration directly from the philosopher's intellectual activity and social experience. In a most vivid way, this work features Plutarch's "small world", a distinguished company of intimates, philosophers, scholars, artists, local magistrates, and high officials of the imperial administration from various regions of the Roman Empire.

The recording of these friendly and select committees devoted to shared knowledge and pleasure is
[1] This paper is a translation of « Le divin Platon à la table des Grecs et des Romains. Dynamiques et enjeux de la fabrique d'une mémoire savante dans l'Empire gréco-romain » (to be published in Frédéric Chapot, Johann Goeken \& Maud Pfaff [ed.], Figures mythiques et discours religieux dans l'Empire gréco-romain, Turnhout). We are grateful to the editors who gave us permission to offer an English version of this paper. We also thank Cynthia Johnson for her advice and suggestions.

[2] VEYNE 2005: 10.

[3] Plutarch, Pericles, 8, 1: "It was from natural sci-

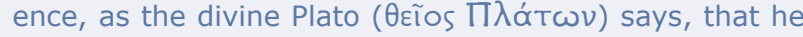
'acquired his loftiness of thought and perfectness of execution, in addition to his natural gifts', and by applying what he learned to the art of speaking, he far excelled all other speakers." (trans. B. Perrin)

[4] Plutarch, Quaestiones convivales. Moralia. Vol. VIII and IX, Cambridge - London, 1961-1969 (Loeb Classical Library), with an English translation by Paul A. Clement (Books I-III), Herbert B. Hoffleit (Books IV-VI), Edwin L. Minar (Books VII-VIII) and F. H. Sandbach (Book IX). Research on Plutarch's Quaestiones Convivales has recently received renewed attention with new questions and topics being addressed, which have now placed this long under-explored work at the very forefront of the Plutarchan studies. Since the publication of TEODORSSON 1989-1996, a large body of academic literature has greatly enriched our understanding of this work. Evaluating the Quaestiones Convivales in light of the philosophical Symposium codes and literary traditions, from Plato to Athenaeus (see for instance: FRAZIER 1994, ROMERI 2002), scholars have explored the subtle narrative strategies that configure the Plutarchan enunciation and writing (HARRISON 2000, KöNIG 2007). At the same time, several studies have endeavoured to locate the Quaestiones Convivales in early Roman-Empire miscellanistic literature and its socio-cultural landscape (one should mention here: SCHMITT-PANTEL 2011: 471-482, JACOB 2005, KLOTZ \& OIKONOMOPOULOU 2011, VAMVOURY-RUFFY 2012, KÖNIG 2012: 60-89; more recentIy, GEORGIADOU \& OIKONOMOPOULOU 2017 also gather several contributions dedicated to the analysis of space and time in the Quaestiones convivales).

[5] Plutarch, Quaestiones convivales, I (prologue), $612 \mathrm{E}$. The Quaestiones convivales involve a few hundred characters - identifiable at least by a name - from various geographical origins and intellectual specialities (on the prosopography of Plutarch's circles of sociability: PUECH 1992; see also the appendices of NIKOLAIDIS 2017: 269270 , for an overall view of the participants, places and hosts in the Quaestiones convivales). The banquets reported in Plutarch's sympotic "memories" are about sixty in number and located, for the vast majority, in the Greek cities of Achaia, particularly in a small area extending from Athens to the Thermopylae, including the home city of Chaeronea. The "welcome-dinner"

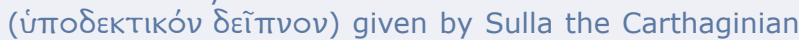
during one of Plutarch's stays in Rome (VIII, 7-8) is the only symposium that takes place outside Greece (even if, as pointed out by NIKOLAIDIS 2017: 264-267, other dinner-parties of the Quaestiones convivales may probably have been hosted in Rome). In this regard, the combination of the characters' profiles with the location of the banquets provides a relevant way to grasp the relational and geographical dynamics of Plutarch's sympotic world, which is both deeply embedded in the microcosm of the Greek poleis and open to the imperial world. On these aspects, see the exploratory propositions we have recently developed using social network analysis: ANDURAND 2015, ANDURAND \& BONNET 2016. 
supposedly based on the narrator's and main protagonist's memory. In this regard, it is worth recalling

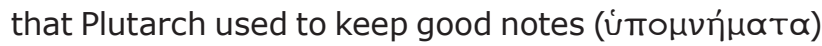
of his readings and of the conversations he had been involved in [6]. However, the description of these informal gatherings in no way precludes the skilful use of fictional resources and devices. The Quaestiones convivales can therefore be treated as a literary work in its own right. Inspired by Plutarch's erudite and encyclopaedic imagination, this collection of sympotic narratives actually gives shape to a learned polyphony in which the distribution of roles and speech, the game of questions and answers, the sharing of anecdotes and traditions, and the performance of knowledge are directed by a sophisticated scenography.

Right from the prologue of the first book, Plutarch intends to relate this narrative programme to the category of memory. Meditating the respective virtues of memory and oblivion within the sympotic sphere, the author addresses the following words to Sosius Senecio:

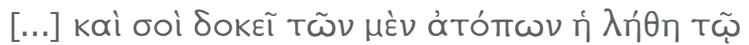

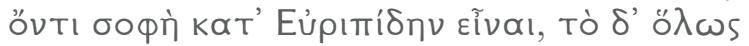

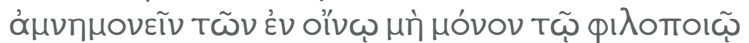

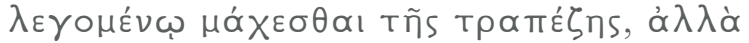

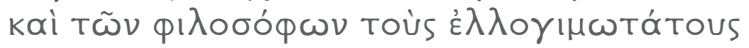

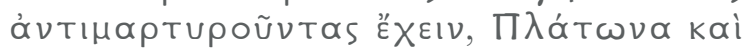

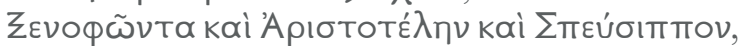

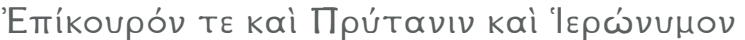

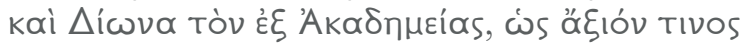

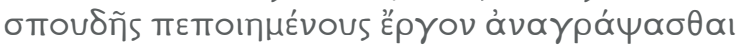

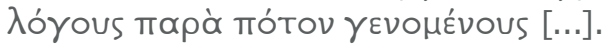

[...] You too, Senecio, believe that forgetfulness of folly is in truth "wise", as Euripides says, yet to consign to utter oblivion all that occurs at a drinking-party is not only opposed to what we call the friend-making character of the dining-table, but also has the most famous of the philosophers to bear witness against it, - Plato, Xenophon, Aristotle, Speusippus, Epicurus, Prytanis, Hieronymus, and Dio of the Academy, who all considered the recording of conversations held at table a task worth some effort [...]. [7]

This preliminary section clarifies the traditions to which Plutarch's writing project can be related. By assigning his book the purpose of collecting, "writing

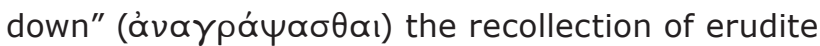
sympotic conversations, he proposes a work of memory operating in the mode of óvó, of recalling and reactivation. In this regard, the Quaestiones convivales can be seen as an ơvóuvnoıs of shared moments devoted to $\varphi \mathrm{I} \lambda \mathrm{i}$ a and knowledge. Yet also - as suggested by the enumeration of philosophers who preceded the author in this exercise - they can be seen as an ơvóß $\alpha \sigma 15$, as a return to the sources of Greek cultural memory and traditions, through the conversation in the present tense with figures and works from the past.

These variations on the theme of memory offer a possible starting-point to engage with the treatment of Plato's figure in the Quaestiones convivales. In the prologues addressed to Sosius Senecio, as in the succession of the narrative sequences that structure each book, the philosopher actually appears as one of the key references of Plutarch's sympotic world. We argue that the exploration of this tutelary figure and the analysis of his significance within Plutarch's discourse provide a privileged field for highlighting the dynamics that support, within the Graeco-Roman Republic of letters, the making of a shared cultural memory firmly related to mythical or "mythologised" figures. First, we will identify the marks of Plato's presence in various aspects of Plutarch's text. Attention will then turn to the symbolic function of Plato's figure as a "patron saint" of Plutarch's philosophical community and paragon of Greek culture, now extended to the limits of the Pax Romana. Finally, in light of this specific case-study, this paper will investigate the interweaving of memory and presence within the Greek cultural traditions that shape Plutarch's sympotic model as the literary microcosm of an expanding Graeco-Roman Empire.

\section{PLATO IN PLUTARCH'S QUAESTIONES CONVIVALES}

Plato's presence manifests at multiple levels of Plutarch's text, in which the philosopher's figure is continuously enriched with cultural meanings. First, Plato's name is mentioned in three of the nine prologues [8], which consist - as Plutarch argues at the beginning of
[6] SIRINELLI 2000: 381.

[7] Plutarch, Quaestiones convivales, I (prologue), 612D-E.

[8] References to Plato's Symposium take place in the prologues of the first book (612D) and of the sixth book
(686B-D), in which Plutarch also alludes to the sobriety of the feasts given in the Academy. Lastly, Plato's name features in the prologue of the third book (645A), which refers to the idea - borrowed from the Laws (I, 649d$650 a)$ - that "most men show their real nature most clearly when they drink." 


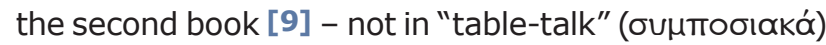

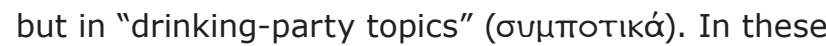
preliminary sections, Plato is referred to as one of

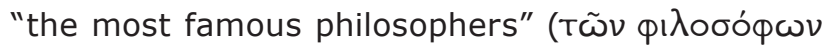

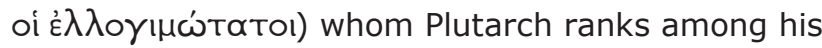
predecessors. The inaugural display of this patronage therefore establishes a direct filiation with Plato's archetypal Symposion. From the very first section of the work, such a reference places the Quaestiones convivales in the continuity of a prestigious literary and philosophical tradition - a tradition that Plutarch would also revisit in connection with the transformations of the Greek culture in the imperial world [10].

In addition to the prologues addressed to Sosius Senecio, the content of the discussions in the Quaestiones convivales shows the importance given to Plato's figure throughout the nine books. Regarding this particular aspect, it is worth noting that the various conversations reported in the course of Plutarch's narration seem to follow a homogeneous scenario, based on highly codified and ritualised practices [11]. Once a specific question has been formulated and put

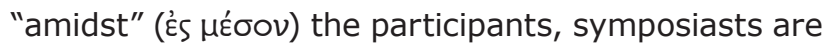
invited to take turns so as to "bring their contribution"

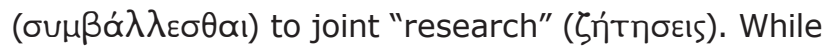
taking the floor, each of them is asked to provide evi-

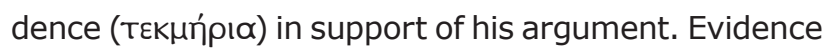

can be derived from experience and from the observation of everyday life. In most cases, however, it relies on the testimony ( $\mu \alpha \rho$ rúpiov) of those whom the

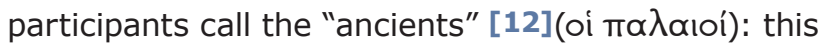
includes for instance quotations, arguments, theories, images or anecdotes borrowed from an author or work from the Greek past [13].

Plato holds a privileged position in every aspect of this literary and erudite game, conceived of as an all-embracing exploration and collective performance of Greek cultural memory. The research conducted by Plutarch's symposiasts certainly reveals some familiarity with the philosopher's thought, common to both Greeks and Romans. First, Plato and his work happen to be one of the guests' favourite topics. Four of the questions collected in the Quaestiones convivales [14] correspond to the genre of Platonicae quaestiones to which Plutarch also dedicated a separate work. These "platonic" questions are directly inspired by the reading and study of Plato's dialogues, although this case is rather rare in the Quaestiones convivales [15]. Furthermore, the philosopher features prominently amongst the references and authorities that Plutarch's symposiasts continuously use, quote or discuss. In this regard, Plato is second only to Homer, but ranks ahead of any other author from the Greek past [16]. The most frequently discussed dialogues are the Symposium,
[9] Plutarch, Quaestiones convivales, II (prologue), 629D.

[10] Plutarch's embracing of this Tapá $\delta \varepsilon ı \gamma \mu \alpha$ does not preclude some elements of differenciation and adaptation. For instance, unlike Agathon's guests, Plutarch's symposiasts gladly encourage the performing of music and poetry at their tables. Moreover, as recently pointed out by Johann Goeken, Plutarch also departs from Plato's literary and philosophical model by promoting rhetoric as "une pratique acceptable et même nécessaire au banquet". "Cette adaptation au contexte socioculturel de I'Empire, Johann Goeken convincingly argues, implique de réserver une place à la rhétorique, laquelle constitue un réflexe, mais aussi une valeur cardinale pour les élites gréco-romaines. La rhétorique n'est plus une nouveauté qui fait peur. Elle est au contraire bien ancrée dans la vie quotidienne de Plutarque et de ses amis. Mais surtout elle participe d'une vision normative et consensuelle, qui est en accord avec l'éthique traditionnelle du banquet, sans empêcher a priori l'éclosion d'un vrai dialogue aussi bien entre convives, à l'occasion d'un banquet circonscrit, qu'entre Grecs et Romains dans l'espace global de I'Empire." (GOEKEN 2017: 287-288).

[11] On the codes and rules which regulate the sharing of speech and knowledge in Plutarch's sympotic world, see KöNIG 2012: 66-81.

[12] BRÉCHET 2003 has made insightful comments on the role of the ancients in Plutarch's works. One may here cite the concluding remark of his paper (p. 550): "L'œuvre de Plutarque témoigne ainsi de la participation dynamique des palaioi à une pensée, dans un foisonnement de vie dont les discussions des Propos de table sont sans doute la preuve la plus éloquente."
[13] From the Greek past only: all references and quotations made by Plutarch's symposiasts derive without exception from the traditions of Greek literature.

[14] See Quaestiones convivales VII, 1 (Against those who find fault with Plato for saying that drink passes through the lungs), VII, 2 (Who the "horncast" man is, of whom Plato speaks), VIII, 2 (What Plato meant by saying that God is always doing geometry), and IX, 5 (Why did Plato say that the soul of Ajax came twentieth to the drawing of lots).

[15] Whereas six questions relate to Homeric scholarship (II, 5; V, 8; V, 10; VI, 9; IX, 4; IX, 13), only two of them explicitly derive from the study of one particular author's work. The first one (II, 1) is derived from Xenophon's Cyropaedia, while the other (VIII, 7) is dedicated to the Pythagorean allegorical precepts.

[16] According to our preliminary survey, the nine books of the Quaestiones convivales contain more than four hundred references to authors or works from the Greek past. Almost one fifth of them relate to Homer (most frequently to Iliad for two thirds of them). Angelo Giavatto has identified 64 references to Plato's dialogues in this work (GIAVATTO 2010; see also, for Plutarch's Moralia as a whole: HeLmBold \& O'NeIL 1959 and Brouillette \& GiavatTo 2010). Furthermore, while the references made by Plutarch's symposiasts over their conversations address numerous domains of Greek literature and knowledge (such as epic poetry, tragedy, comedy, poetry, and medicine), a systematic count shows that, for philosophy, Platonic traditions are the most frequently discussed traditions, ahead of pre-Socratic (Empedocles, Democritus, Pythagoras) or Peripatetic (Aristotle, Theophrastus) authors. 
the Republic and the Timaeus, the Phaedrus and the Laws, in descending order.

The Platonic tone of the Quaestiones convivales, in terms of discussion topics, research material and literary references, is consistent with the intellectual composition of the group staging in the course of Plutarch's narration. To various degrees, Platonism is actually the most represented philosophical school among the symposiasts. Mention should made here

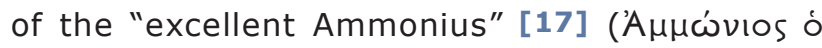

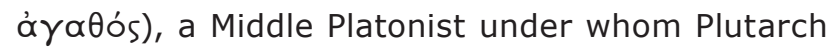
studied in his early Athenian years and to whom he significantly gives the final words of the Quaestiones convivales [18]. In addition to the former master, this small Platonic community also includes Plutarch's own disciples, the young Hagias and Aristainetos, who make a short appearance at a Chaeronean banquet [19]; Favorinus of Arelate, one of Mestrius Florus' guests in his Thermopylae residence - the young philosopher is still described, though, as an "enthusiastic admirer

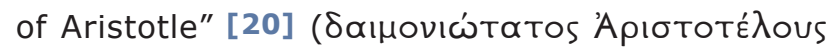
غ́paotńs); Themistocles the Athenian [21], a distant descendant of the illustrious magistrate who also studied with Ammonius [22] before embracing stoicism; Hylas the grammarian - also presumably an Athenian - portrayed as an expert on Plato's works and thought [23].

These few observations are sufficient to show Plato's utmost importance in the Quaestiones convivales. Referred to as an inspirational model of Plutarch's literary agenda, the philosopher is also one of the key figures of the Plutarchean sympotic world. For Plutarch's characters, Plato is not only a preferred reference, the philosopher par excellence, but also a source of mediation and authority with whom only Homer - "the Poet" (o Moıntńs) - can compete. Through some episodes and practices developed in the narration of the Quaestiones convivales, for Plutarch's symposiasts Plato therefore becomes a symbolic and ideal figure, whose significance extends beyond admiration and intellectual attachment.

\section{PLATO AS "PATRON SAINT" OF PHILOSOPHERS AND OF GREEK CULTURE}

From the first prologue of the Quaestiones convivales, the ritualised stage of banquet is placed under the patronage of the Muses and Dionysus [24]. The latter is indeed called Lysios or Lyaios, "the Looser and the Liberator of all things", who "unbridles the tongue and grants the utmost freedom to speech." [25] Combined with the inspiration that the Muses and the Nymphs grant to wise men, poets, and other "masters of truth", Dionysus' liberating power transforms the banquet into a place of '̇ $\lambda \varepsilon v \theta \varepsilon \rho i ́ \alpha$ and $\pi \alpha \rho \rho \eta \sigma i ́ \alpha$. Performed between inspiration, ritual and agonistic ethos, the symposiasts' ensemble and skilful jousts focus more on persuasion than on demonstration. Their purpose is articulated in terms of balance, charm and pleasure. That is why the banquet stage does not lend itself to any speeches or evocations. Turning away from "foolish stories,

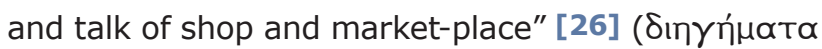

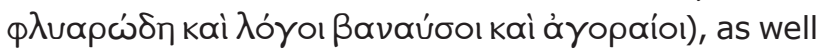
as from pedantic disputes, all unworthy of Dionysus,

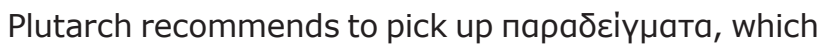
are likely to encourage the participants to pursue philosophy, piety [27], and good and humanitarian
[17] Plutarch, Quaestiones convivales, IX, 15, 748D.

[18] Ammonius features on three occasions over the nine books of the Quaestiones convivales - each time in an Athenian context. He is present among the guests of Erato the Musician (III, 1-2) and also hosts two banquets. The first one is reported by Plutarch in VIII, 3, whereas the whole ninth book is centred on the second gathering, which brings together "nearly all our friends" and "quite a number of other men with literary interests" (736D) at the Muses' feast in Athens.

[19] This gathering takes place at the home of Plutarch's father in Chaeronea (III, 7-9). Hagias and Aristaenetus are designated as "young men of philosophical temperament" $(655 \mathrm{~F})$ and congratulated for their "ingenu-

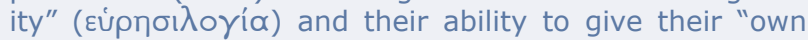
attempts at a solution" (656B) during a conversation on the effects of wine.

[20] Plutarch, Quaestiones convivales, VIII, 10, 734F.

[21] This character makes a single appearance at a banquet given by Mestrius Florus $(I, 9)$. On this occasion, the discussion focuses on the cleaning properties of freshwater, with arguments from Chrysippus, Aristotle and Homer.
[22] Plutarch, Themistocles, 32, 6. See also the biographical note of PUECH 1992: 4886.

[23] During the banquet given by Ammonius at the Muses' feast (Quaestiones convivales, IX, 5, 739F-740A), Hylas is urged by the rhetor Sospis to answer a question related to the myth of Er, as follows: "Explain to us, as

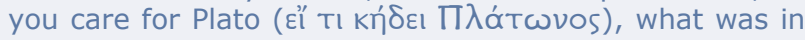
his mind when he described the soul of the Telamonian as having drawn twentieth place when he came forward to choose his fate."

[24] Plutarch, Quaestiones convivales, I (prologue), $612 \mathrm{E}$.

[25] Plutarch, Quaestiones convivales, I, 1, 613C. These words are attributed to Crato, one of Plutarch's relatives by marriage. On this character, see PUECH 1992: 4843.

[26] Plutarch, Quaestiones convivales, I, 1, 615A. Once again, Plutarch's disqualification of market-place talk contrasts with some features of Socrates' discussional habits, as portrayed in Plato's dialogues (see for instance: Symposium, 221e; Apology, 17c; Gorgias, 490c).

[27] Plutarch, Quaestiones convivales, I, 1, 614B. 
actions. $\Phi \mathrm{I} \lambda \mathrm{av} \theta \rho \omega n$ ia is one of the cornerstone values of Plutarch's sympotic world [28]. In these matters, Plato is seen both as a precursor and a model since in his Symposium, he carefully avoids any confusion between banquet and palaestra, between adversarial debate and wrestling [29]. Instead of muscular force, Plato uses flexibility, good exempla, and soberly brings up mythological narratives. As a source of парабєіүната for successful symposia, the philosopher is held up as a dual model: his Symposium both shows proper conduct for philosophical banquets and uniquely exemplifies how to retain a vivid memory of these convivial gatherings for posterity [30]. The exemplary seriousness of Platonic friendly meetings ensures their ơvó $\mu \nu \eta \sigma 15$, which revives the conversations once held by the fellow participants and the pleasure they generated among them. The discussions of old therefore remain fresh and available for the delight of later generations, up to Plutarch's time and even beyond. Plato's paradigmatic narrative transcends time and space and becomes an ideal source of living memory and filiation. In book VII, for instance, Plutarch's symposiasts thus call themselves Plato's

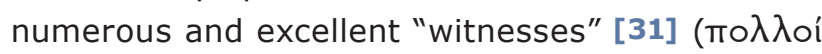

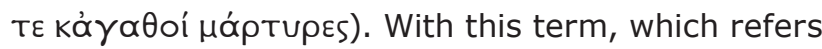
to the legal-religious sphere of oath [32], Plutarch's symposiasts consequently claim a resolute affiliation to Plato.

In order to renew the spiritual bond with their glorious forefather, the participants at Plutarch's banquets actually perform a series of rituals. Such practices periodically confirm and reinforce the sympotic community's status as the latest continuation of an uninterrupted lineage of philosophers, which traces back to Plato and legitimates its position under the divine ancestor's patronage [33]. A passage from the Quaestiones convivales indicates that collective readings of Plato's works used to take place in some banquets in Rome [34], thus creating occasional hermeneutical communities partly comparable to those based on sacred texts in Jewish or Christian circles from the same period [35]. Moreover, even if the exchange of views and dialectics are at the centre of sympotic practices, Plutarch's symposiasts occasionally set themselves up as experts of the Platonic word and as guardians of the temple, concerned with maintaining some form of philosophical orthodoxy [36]. Moreover, during a banquet held at Sextus Sylla's, a Carthaginian grammarian, Plutarch and his fellow participants express strong indignation over the popularity of a practice that has been recently introduced in Roman sympotic gatherings, which consists in performing scenes from Plato's dialogues on the sympotic stage [37]:

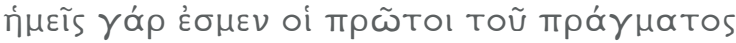

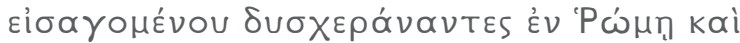

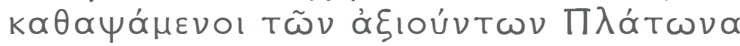

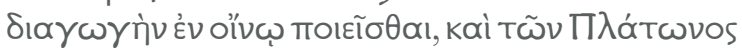

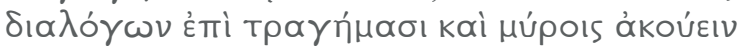

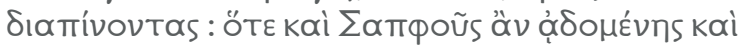

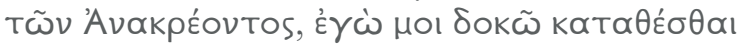

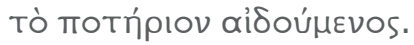

We were the first to be disgusted when this movement was launched in Rome, and the first to attack those who thought fit to regard Plato as a bibulous pastime and to hear his dialogues rendered over their wine and dessert and perfume. Even when Sappho's poems are sung, or Anacreon's, I am moved to put down my cup respectfully.

Aỉós, here associated with Sappho, Anacreon and a fortiori Plato, is a complex feeling. According to Jean Rudhardt [38], it refers to the concern to keep for oneself the conditions needed for a good
[28] On this notion, see KonSTAN 1997 and RIBEIRO FERREIRA et. al. 2009.

[29] Plutarch, Quaestiones convivales, I, 1, 614D-E.

[30] Plutarch, Quaestiones convivales, VI (prologue), 686D: "but they [Plato and Xenophon] preserve in writing only the philosophical discussions, combining fun with serious effort. Thus they have left precedents (парабвіүната) not only in meeting together for good conversation over wine, but in recording ( $\mu \varepsilon \mu \nu \tilde{\sigma} \sigma \theta \alpha \mathrm{l})$ the conversation afterward."

[31] Plutarch, Quaestiones convivales, VII, 1, 698F.

[32] On this notion, see for instance SOMMERSTEIN \& FLETCHER 2007.

[33] For this see KöNIG 2012: 40-52, EsHLEMAN 2012: 177-212.

[34] Plutarch, Quaestiones convivales, VII, 2, 700C:

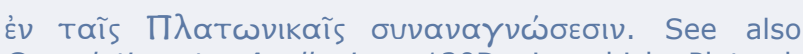
Consolation to Apollonius, 120D, in which Plutarch announces to his friend that he will send him his personal

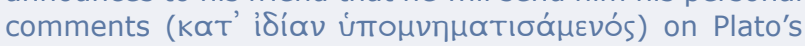
dialogue On the soul. Similarly to a banquet, here correspondence also becomes a space for sharing among Platonic followers.

[35] This parallel is further discussed in ESHLEMAN 2012: 199-212.

[36] Regarding a quote traditionally attributed to Plato, Plutarch suggests (VIII, 2, 718C): "I remarked that while this statement is not made explicitly in any of Plato's writings, it is well enough attested and is in harmony with his character [...]."

[37] Plutarch, Quaestiones convivales, VII, 8, 711D.

[38] RUDHARDT 2001. 


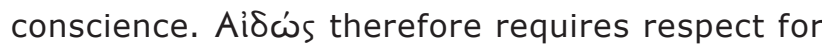

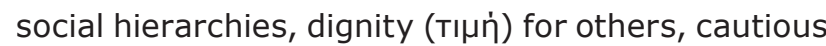
restraint, and ultimately expresses deep and even fearful reverence, originating from the view that others - gods or humans - may take about one's behaviour. The dignity of Plato's texts should then be respected and should arouse an almost religious veneration, associated with proper words, behaviours and contexts.

The most obvious demonstration of some sort of Platonic "cult" in the Quaestiones convivales occurs in the first question of the eighth book during a debate on The days on which certain eminent persons were born. Plutarch alludes to two birthdays that his friendly circle has just celebrated in quick succession [39]:

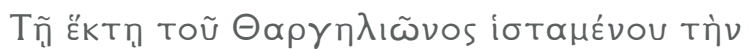

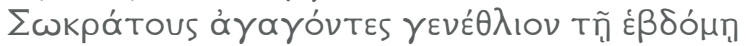

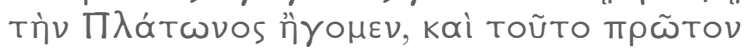

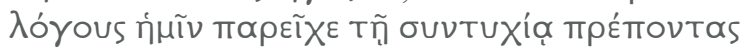
$[\ldots]$.

On the sixth of Thargelion we celebrated the birthday of Socrates, and on the seventh that of Plato, and this coincidence of dates furnished us with our first topic of conversation.

By some remarkable ouvtuXía, construed as a divine sign, the birth of the master (Socrates) happened only one day prior to that of the disciple (Plato). Yet Plato's birthday also implies a connection with Apollo - whose birthday, on the $7^{\text {th }}$ of Thargelion, used to

[39] Plutarch, Quaestiones convivales, VIII, 1, 717B.

[40] Plutarch, Quaestiones convivales, VIII, 1, 717D-E. Diogenes Laertius (III, 2 ) recalls a similar version of this ancient tradition: "Speusippus in the work entitled Plato's Funeral Feast, Clearchus in his Encomium on Plato, and Anaxilaides in his second book On Philosophers, tell us that there was a story at Athens that Ariston made violent love to Perictione, then in her bloom, and failed to win her; and that, when he ceased to offer violence, Apollo appeared to him in a dream, whereupon he left her unmolested until her child was born. Apollodorus in his Chronology fixes the date of Plato's birth in the $88^{\text {th }}$ Olympiad, on the seventh day of the month Thargelion, the same day on which the Delians say that Apollo himself was born." (trans. R. D. Hicks) In the foreword of his treaty On Plato and his doctrine (I, 1-2), Apuleius also refers to Plato's Apollonian filiation: "There are also those who relate that Plato descended from a more august conception, since a certain spectre of Apollo had connexion with Perictione. He was likewise born in the month which is called by the Athenians Thargelion". For his part, Origen evinces some scepticism about these traditions which he considers as mere "myths" (Against Celsus, I, 37): "And yet these are veritable fables, which have led to be celebrated by the Athenians during the Thargelia festival. There is no need to dwell on the symbolic dimension of the number 7, associated with divine completeness, which can apply both to Apollo's powers and Plato's doctrine. However, more attention can be given to Florus' speech on this special occasion, which echoes the parallel calendar for Plato and Apollo:

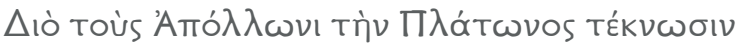

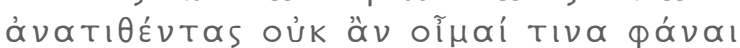

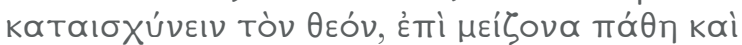

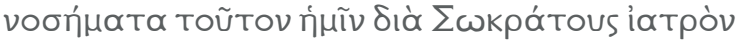

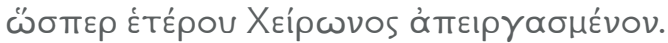

Therefore, I do not think anyone would say that those who attribute Plato's parentage to Apollo are bringing disgrace on the god, who made him, through the agency of Socrates (as if he had been a second Cheiron), a physician to heal greater ailments and sicknesses than those healed by Asclepius.

Plutarch then emphasises this interpretation in his narration: "He [Florus] mentioned the vision which is said to have appeared to Ariston, Plato's father, in his sleep, which spoke and forbade him to have intercourse with his wife, or to touch her, for ten months." [40] Assimilated to Asclepius, a god miraculously born from another god, the divine Plato thus seems to be revered as a doctor for the soul [41]. That is why Tyndares the Spartan may round off the discussion by acclaiming Plato with a quote from Homer [42]: the invention of such stories concerning a man whom they regarded as possessing greater wisdom and power than the multitude, and as having received the beginning of his corporeal substance from better and diviner elements than others, because they thought that this was appropriate to persons who were too great to be human beings." See also Prolegomena to Platonic philosophy, $1,16-60$. On the celebration of Thargelia in Athens, see PARKER 2005: 185, 203-204, 481-483.

[41] Olympiodorus (Life of Plato, 3) also mentions this anecdote: "After his decease the Athenians buried him in an expensive manner, and they inscribed upon his tomb 'These two, Æsculapius and Plato, did Apollo beget; One, that he might save the soul; the other, the body'."

[42] Plutarch, Quaestiones convivales, VIII, 1, 717E. The last quote refers to Homer, Iliad, XXIV, 258. On Homeric quotations in Plutarch's work, see BRÉCHET 2005a, BRÉCHET 2005b, BRÉCHET 2008a. C. Bréchet notes that references to Iliad and Odyssey in Plutarch's works also tend to associate the Greeks (as heirs of the Achaeans) with the Romans (as descendants of the Trojans), therefore creating a cultural continuity between them under the glorious auspices of Homer. 


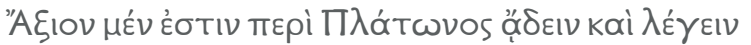

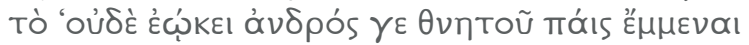

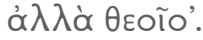

It is fitting to celebrate Plato with the line, "He seemed the scion not of mortal man, but of a god."

This acclamatory ritual, almost conceived of as a theogonical hymn to Plato, is re-enacted every year on the anniversary date [43]. This celebration is coupled with an offering of words and culminates in some sort of Platonic epiphany following the discussion. In the wake of the discussion on Plato's divine filiation, in fact, Diogenianus [44], one of the guests at this special gathering, now invites the participants to investigate a new question [45]:

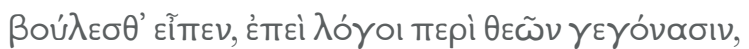

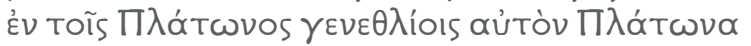

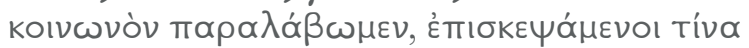

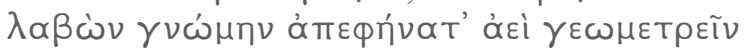

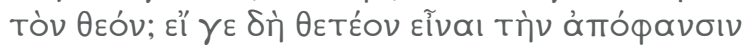

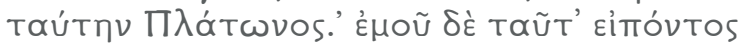

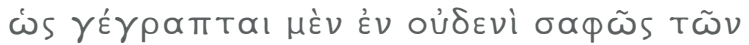

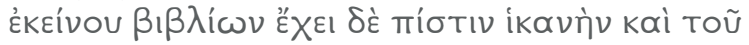

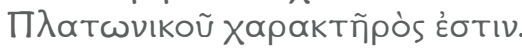

If you please, let us on Plato's birthday take Plato himself as partner in the conversation, and since we have spoken about the gods, consider what he had in mind when he asserted that God is always doing geometry - if indeed this statement is to be attributed to Plato.

Through his thought, Plato actually becomes present "at the centre" ('́s $\mu \varepsilon ́ \sigma \circ \nu$ ) of the sympotic forum, like a god whose word, following the example of Apollo, is destined to be interpreted by followers and prophets. It is also worth recalling that Plutarch used to serve as a priest in Delphi. [46] As son and emulator of Apollo, Plato delivers a divine, inspired and partly cryptic message, which his heirs aim at discussing and relaying in the context of sympotic ritual placed under Dionysiac and Apollonian auspices. In welcoming and gathering Plato's masterly thought through doxographical comments, the participants legitimate their own discourse and position, thus receiving part of their divine model's power and prestige.

\section{FROM MEMORY TO PRESENCE}

In the ritualised world of the banquet, Plato's founding and living figure gives shape to a spiritual community, based on the reference to a continuously recreated and reactivated heritage. The collective performance achieved through a series of cultural and intellectual operations - such as questions, discussions, references, quotations - involves the participants' cultural memory and identity, far beyond a mere mimetic posture [47]. Quotations from great works of the past and references to ancient authors acquire psychagogic

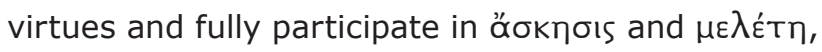
both orientated towards work on oneself, the daily use of precepts as a means of action and decision. In other words, references to and community with authors from the past [48] - Plato in primis - are conceived of as a key resource for naıঠzia.

The pooling and activation of scholarship, as displayed in Plutarch's Quaestiones convivales, also operate at different scales and levels. In spite of the
[43] Eusebius, Praeparatio evangelica, X, 3 also refers to the celebration of Plato's birthday in Athens: "When Longinus was entertaining us in Athens at the banquet in memory of Plato (tò $\Pi \lambda \alpha T \omega ́ v \varepsilon \mid \alpha$ ), he had invited among many others. [...] Prosenes also said: 'The other plagiarists you have detected: but that even this hero Plato himself, after whom the feast which we are celebrating today is named, makes use of many works of his predecessors (for in his case I feel too much respect

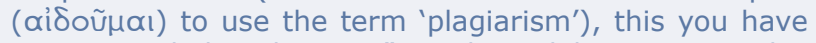
not proceeded to discover." On this celebration, see also Porphyry, Life of Plotinus, 2: "But he [Plotinus] never told anyone the month in which he was born or the day of his birth, because he did not want any sacrifice or feast on his birthday, though he sacrificed and entertained his friends on the traditional birthdays of Plato and Socrates; on these occasions those of his friends who were capable of it had to read a discourse before the assembly company"; 15 : "At Plato's feast I read a poem, The Sacred Marriage; and because much in it was expressed in the mysterious and veiled language of inspiration someone said, 'Porphyry is mad.' But Plotinus said, so as to be heard by all, 'You have shown yourself at once poet, philosopher, and expounder of sacred mysteries."' (trans. A. H. Armstrong). See also Prolegomena to Platonic philosophy, 6, 9-22. Lastly, it should be mentioned that Lorenzo de Medici used to celebrate Plato's birth and death in his Careggi villa. Marsilio Ficino has preserved the memory of this event; Lorenzo used to invite nine guests: the number of the Muses, but also the number of participants in Plato's Symposium.

[44] Diogenianus of Pergamon, a friend of Plutarch, to whom he pays tribute in his treaty De Pythiae oraculis, 395A. See PUECH 1992: 4846.

[45] Plutarch, Quaestiones convivales, VIII, 2, 718B-C.

[46] On this aspect of Plutarch's life: BouLOGNE 1994.

[47] On the meaning of quotation as a genuine act of creation, based not on mere reproduction but on the appropriation of a literary model, see BRÉCHET 2007 and BRÉCHET 2008b.

[48] On the notion of "community" with the past: KöNIG 2012: 76 . 
overrepresentation of Greece in terms of locations, characters, and cultural references, Plutarch's sympotic world introduces a few hundred scholars from all over the Roman Empire, with various intellectual specialities and philosophical orientations. In this regard, the Quaestiones convivales mirror the cosmopolitism of the Graeco-Roman Empire and the universal potential of Greek culture. Plutarch's sympotic microcosm is created in the image of the Graeco-Roman Empire macrocosm, politically attracted to the Roman centre but culturally shaped by the Greek heritage. The scholarly networks portrayed in the Quaestiones convivales widely spread out from Plutarch and gradually expand their ramifications into the oecumene thanks to the benefits of the Pax Romana. This Plutarchian ego-network also includes potentially expanding concentric circles. These sociability dynamics developed from Plutarch's home city in Chaeronea to all regions of Greece, bringing Rome and Greece together and ultimately gathered symposiasts from a large Mediterranean area, including regions such as Asia Minor, Gaul and Egypt. Despite this declared universalism, Plutarch's sympotic world and high intellectual performances draw a dividing line between scholars and others, between the custodians of a prestigious and living cultural heritage and ordinary people who possess little knowledge of that heritage. The Plutarchian banquets relate only to the elite of $\Pi \varepsilon п a ı \varepsilon \varepsilon u \mu \varepsilon \dot{\varepsilon}$ ol, promoting the above-mentioned cultural and moral values in front of invisible spectators, who have no place on the sympotic stage. Furthermore, as recently pointed out by Jason König [49], epigraphical euergetical evidence related to sacrificial banqueting and festival records in the Early Imperial Greek poleis, with their emphasis on benefactors and guests from all over the Empire, are in line with a similar universalising logic. In both cases, the discourse emphasises cosmopolitism and shared values - such as hospitality and sociability that permeate a new global world. The contribution of prestigious families to the development of such a shared and selective space relied on the reactivation of ancestral cultural traditions, inherited from a glorious past and orientated towards a solid future.

[49] KöNIG 2012: 81-88. See also KöNIG 2011: 195 202. J. König's analysis here corroborates C. Bréchet's remarks on the relations between orality, memory and the ontological status of quotation (as a philosophical practice and restitution of living word) in Plutarch's work and ancient literature (see BRÉCHET 2007: 101-105).

[50] On this notion, see particularly ESHLEMAN 2012: 177-199.

[51] Apuleius, Apology, 64: "But we of the family of Plato (Platonica familia) know naught save what is bright and
All in all, Plutarchian scholarly circles, as portrayed in the Quaestiones convivales, were inclusive, in view of a multicultural Empire that has adopted Greek culture as the medium and cornerstone of diversity. Nonetheless, they also evince elective aspects that enhance the importance of an elite invested with a mission in time and space. In this regard, Plutarch's sympotic circle

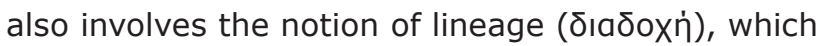
consolidates community through temporal succession and heritage transmission [50]. Transcending historical contingencies, lineage combines the limited temporality of sympotic gatherings (which activates sociability and intellectual performances at periodic intervals) with long-term notions of knowledge translation, intellectual filiation, and cultural traditions. Based on both circle and lineage, the Plutarch's community tends to become a family - to use a term that accurately expresses this twofold dimension of the sympotic experience. The Plutarchian world of banquets, as regular assemblies of Plato's spiritual sons, foreshadows Apuleius' notion of Platonica familia [51]. Through the reference to their patron saint, Plutarch's symposiasts associate their existence with a mythical past, reactivating through sympotic rituals a founding golden age full of "what is bright and joyous, majestic and heavenly and of the world above us".

Anamnesis plays a key role in this back and forth movement between past and present, between Plato and his descendants. Recalling the discussions during the days of Plato and Socrates, reenacting the verbal jousts of old, giving voice to great authors from the past and maintaining a personal relationship with them [52]: these strategies all help give substance to a living philosophical community. Moreover, is not

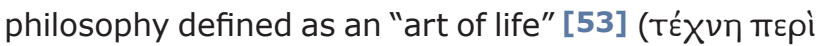
Bíov) bridging past and present, knowledge and pleasure, culture and power? Just as in Lucian's Dialogues of the Dead and Discussion with Hesiod, the past is invoked as an accessible and invigorating horizon, as a symbolic capital for present and contemporaries' delight. When Plutarch's company, after having celebrated Plato's anniversary, proposes to discuss one of the philosopher's thoughts in order to honour

joyous, majestic and heavenly and of the world above us. Nay, in its zeal to reach the heights of wisdom, the Platonic school has explored regions higher than heaven itself and has stood triumphant on the outer circumference of this our universe".

[52] While Philip of Prusa, for instance, one of Plutarch's guests in Chaeronea, refers to Euripides as his pi $\lambda$ os (VII, 7, 710E), Favorinus is described as an Épootńs of Aristotle (VIII, 10, 734F).

[53] Plutarch, Quaestiones convivales, I, 1, 613B. 
him, they invite their glorious and divine ancestor to participate in the conversation: "let us take Plato himself as partner in the conversation", suggests Diogenianus [54]. Amidst the excitement of a merry symposium, a sophisticated dialogue then starts for the sake of those present, not of any fossilised heritage - with authors from the past embodying the vitality and excellence of Greek culture. Through an analysis of the quotations in the Quaestiones convivales, Jason König rightly observes that the lexicon used by Plutarch and his fellow symposiasts to call on the testimony and authority of the ancients is predominantly related to oral communication [55]. In the Quaestiones convivales, memory means first and foremost conversation with past authors and bringing their presence to life. The symposiasts' collective performance here echoes the ambition Plutarch develops in the prologue of the sixth book, placed under Platonic inspiration [56] :

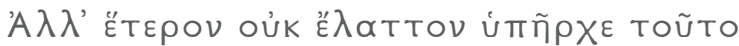

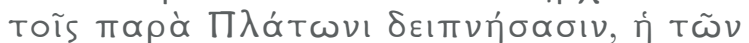

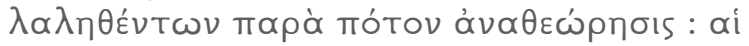

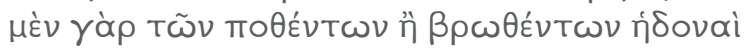

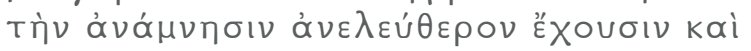

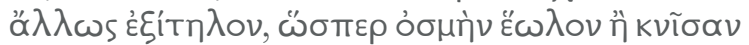

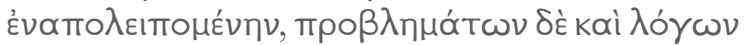

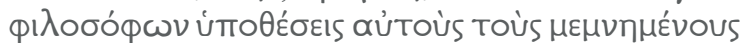

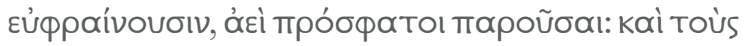

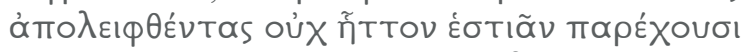

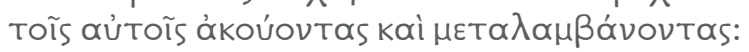

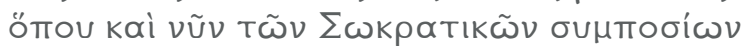

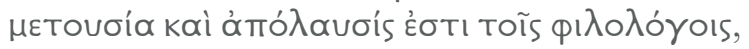

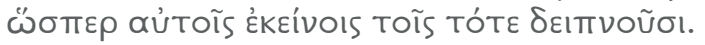

Another and not less valuable privilege guaranteed to Plato's guests was that of recalling afterwards what had been said over the drinks. Remembering past delights in food and drink is an ignoble kind of pleasure and one that is, besides, as unsubstantial as yesterday's perfume or the lingering smell of cooking. On the other hand, the topics of philosophical inquiry and discussion not only give pleasure by remaining ever present and fresh to those who actually recall them, but they also provide just as good a feast on the

[54] Plutarch, Quaestiones convivales, VIII, 2, 718C. [55] KöNIG 2012: 76-77.

[56] Plutarch, Quaestiones convivales, VI (prologue), 686B-C.

[57] Plutarch, Quaestiones convivales, VII, 1, 700B. same food to those who, having been left out, partake of them through oral report. In this way, it is even to-day open to men of literary taste to enjoy and share in the Socratic banquets as much as did the original diners.

As initiators of a philosophical banquet now enshrined for posterity, Socrates and Plato are honoured in the Plutarchian world of learned banquets as inspirational models for thought and action, and as indispensable vectors of naıঠzia, which now must be further transmitted and spread far beyond the boundaries of historical Greece.

From a single paradigmatic case, the image and uses of Plato's figure in the Quaestiones convivales shed fresh light on the dynamics supporting the creation of a shared cultural memory within the Graeco-Roman Empire. Through the conversations and practices in the Plutarchian world of banquets, Plato, "a philosopher pre-eminent in reputation and in influence" [57], is inducted as a patron saint, a tutelary figure in reference to which the symposiasts develop part of their own cultural identity. As the focal point of both a hermeneutical and ritual community, Plato operates - to use another metaphor - as a бú $\mu ß 0 \lambda$ ov that successively signals affiliation with an intellectual circle and connection to a spiritual lineage. As a guarantee of legitimation and integration, adherence to Plato's "mythicized" figure, which is exhibited within the time frame and collective performance of banquets, mobilises those in attendance: along with the collective exploration of cultural memory and by emulating the ancients, scholarship not only involves ritualised sharing, but also becomes a moral imperative and the source of truth.

The Plutarchian theme of the divine Plato therefore exemplifies some of the recompositions guiding the development of a Graeco-Roman Empire at the beginning of the Antonine period. Assembled from the materials in circulation among the disciples of the Academy as early as the $4^{\text {th }}$ century BCE, this tradition takes on new significance in the Quaestiones convivales. Attention has been drawn on the longevity of Plato's Apollonian ancestry, which was still celebrated in Rome and in Athens in the $3^{\text {rd }}$ century CE. The Pluarchian motif of the divine Plato, which was carried further and amplified in Imperial literature from Apuleius's Platonica familia to the neo-platonic circles around Plotinus and Longinus, therefore becomes the expression of a reinvented Greek culture, conceived of as the language and reference of a new Mediterranean-wide cultural area. 
Andurand, Anthony, 2015, «Le monde plutarquéen des banquets savants : essai d'approche spatiale », Histoire et informatique 19, p. 64-71.

Andurand, Anthony \& Bonnet, Corinne, 2016, « "Les coutumes et les lois des nations barbares" (Plut., QC 2, 1). Réseaux savants entre centre et périphérie dans les Propos de table de Plutarque », in Sydney Aufrère \& Frédéric Möri (ed.), Alexandrie la divine. Sagesses barbares. Échanges et réappropriations dans l'espace culturel gréco-romain, Genève, p. 109-141.

Boulogne, Jacques, 1994, Plutarque. Un aristocrate grec sous l'occupation romaine, Lille.

BrÉCHet, Christophe, 2003, « Les palaioi chez Plutarque », in Béatrice Bakhouche (ed.), L'ancienneté chez les Anciens. II : Mythologie et religion, Montpellier, p. 519-550.

BRÉCHET, Christophe, 2005a, «L'influence des Alexandrins sur les citations homériques de Plutarque et leur commentaire », in Angelo Casanova (ed.), Plutarco e l'età ellenistica, Firenze, p. 243-268.

BRÉCHET, Christophe, 2005b, « La lecture plutarquéenne d'Homère : de la Seconde Sophistique à Théodore Métochite », Pallas 67, p. 175-201.

BRÉCHet, Christophe, 2007, « Vers une philosophie de la citation poétique : écrit, oral et mémoire chez Plutarque », Hermathena 182, p. 101-134.

BRÉCHET, Christophe, 2008a, « Grecs, Macédoniens et Romains au test d'Homère : référence homérique et hellénisme chez Plutarque », in Anastasios Nikolaidis (ed.), The Unity of Plutarch's Work: Moralia Themes in the Lives, Features of the Lives in the Moralia, Berlin, p. 85-109.

BRÉCHET, Christophe, 2008b, « Sur la prétendue dimension mimétique de la citation en Grèce ancienne 》, in Danièle Auger \& Étienne Wolff (ed.), Culture classique et christianisme. Mélanges offerts à Jean Bouffartigue, Paris, p. 259-273. Brouillette, Xavier \& Gravatro, Angelo, 2010, « Les dialogues platoniciens chez Plutarque. Une introduction », in Xavier Brouillette \& Angelo Giavatto (ed.), Les dialogues platoniciens chez Plutarque. Stratégies et méthodes exégétiques, Louvain, p. 1-25.

EshlemAN, Kendra, 2012, The Social World of Intellectuals in the Roman Empire: Sophists, Philosophers, and Christians, Cambridge.

FrAZIER, Françoise, 1994, «Deux images des banquets de lettrés : les Propos de Table de Plutarque et le Banquet de Lucien », in Alain Billault (ed.), Lucien de Samosate, Lyon, p. 125-130.

Georgiadou, Aristoula, \& Orkonomopoulou, Katerina (ed.), 2017, Space, Time and Language in Plutarch, Berlin. Giavatto, Angelo, 2010, «Répertoire des citations de Platon dans les Moralia », in Xavier Brouillette \& Angelo Giavatto (ed.), Les dialogues platoniciens chez Plutarque. Stratégies et méthodes exégétiques, Louvain, p. 131-141.

Goeken, Johann, 2017, «Plutarque et la tradition rhétorique du banquet », in Aristoula Georgiadou \& Katerina Oikonomopoulou (ed.), Space, Time and Language in Plutarch, Berlin, p. 279-288.

HARRIson, George W. M., 2000, « Problems with the Genre of Problems: Plutarch's literary Innovations 》, Classical Philology 95.2, p. 193-199.

Helmbold, William C. \& O’NeIl, Edward N., 1959, Plutarch's Quotations, Oxford.

ЈАСов, Christian, 2005, «La table et le cercle. Sociabilités savantes sous l'Empire romain », Annales HSS 3, p. 507-530. Klotz, Frieda \& Orкonomopoulou, Katerina (ed.), 2011, The Philosopher's Banquet. Plutarch's Table Talk in the Intellectual Culture of the Roman Empire, Oxford.

KöNIG, Jason, 2007, «Fragmentation and Coherence in Plutarch's Sympotic Questions », in Jason König \& Tim Whitmarsh (ed.), Ordering Knowledge in the Roman Empire, Cambridge, p. 43-68.

KöNIG, Jason, 2011, « Self-Promotion and Self-Effacement in Plutarch's Table Talk», in Frieda Klotz \& Katerina Oikonomopoulou (ed.), The Philosopher's Banquet. Plutarch's Table Talk in the Intellectual Culture of the Roman Empire, Oxford, p. 179-203.

KöNIG, Jason, 2012, Saints and Symposiasts. The Literature of Food and the Symposium in Greco-Roman and Early Christian Culture, Cambridge. 
Konstan, David, 1997, Friendship in the Classical World, Cambridge.

Nrkolaidis, Anastasios G., 2017, « Past and present in Plutarch's Table Talk », in Aristoula Georgiadou \& Katerina Oikonomopoulou (ed.), Space, Time and Language in Plutarch, Berlin, p. 257-270.

PARKeR, Robert, 2005, Polytheism and Society in Ancient Athens, Oxford.

Puech, Bernadette, 1992, «Les amis de Plutarque », in Aufstieg und Niedergang der römischen Welt II, 33.6, Berlin - New York, p. 4831-4893.

RIBeIRo Ferreira, José et. al. (ed.), 2009, Symposion and Philanthropia in Plutarch, Coimbra.

RomerI, Luciana, 2002, Philosophes entre mets et mots. Plutarque, Lucien, Athénée autour de la table de Platon, Grenoble.

RUDHARDT, Jean, 2001, «Quelques remarques sur la notion d'aidôs », in Édouard Delruelle \& Vinciane PirenneDelforge (ed.), Kêpoi : De la religion à la philosophie. Mélanges offerts à André Motte, Liège, p. 1-21.

Schmitt-Pantel, Pauline, 2011, La cité au banquet. Histoire des repas publics dans les cités grecques, 2nd ed. (1st ed. 1992), Paris.

Sirinelli, Jean, 2000, Plutarque de Chéronée. Un philosophe dans le siècle, Paris.

Sommerstein, Alan H. \& Fletcher, Judith (ed.), 2007, Horkos. The Oath in Greek Society, Exeter.

TEOdORSSON, Sven-Tage, 1989-1996, Commentary on Plutarch's Table Talks, Göteborg.

Vamvoury Ruffy, Maria, 2012, Les vertus thérapeutiques du banquet. Médecine et idéologie dans les Propos de Table de Plutarque, Paris.

Veyne, Paul, 2005, L'Empire gréco-romain, Paris, 2005. 